\title{
THE INTERNATIONAL CRIMINAL COURT: BETTER THAN NUREMBERG?
}

\author{
Tonya J. Boller
}

\section{INTRODUCTION}

If certain acts in violation of treaties are crimes, they are crimes whether the United States does them or whether Germany does them, and we are not prepared to lay down a rule of criminal conduct against others which we would be unwilling to have invoked against us.-Justice Robert Jackson, Chief U.S. Prosecutor at Nuremberg.'

Justice Jackson's promise seems empty during the first days of the now permanent International Criminal Court (ICC). ${ }^{2}$ The United States, while participating in prosecuting other countries for atrocities listed as crimes in the Rome Statute, ${ }^{3}$ is reluctant to accept the ICC as a valid extension of law over Americans. ${ }^{4}$ However, fifty-six years ago, the United States was instrumental in establishing the International Military Tribunal to prosecute war criminals in Nuremberg. ${ }^{5}$ Nuremberg was "the first trial in history for crimes against the peace of the world." Following the Nuremberg trials, the United Nations General Assembly' began discussions in an effort to establish a permanent

* J.D. Candidate, 2004, Indiana University School of Law - Indianapolis. The author wishes to thank her family and friends for their continued patience, support, and understanding throughout the writing of this Note, law school, and life in general. The author remembers and also wishes to thank Francis H. and Adele T. Garshwiler and William D. Hevron; may each of their loving souls rest in peace.

1. War CRIMES aND the AMERICAN Conscience 1 (Erwin Knoll \& Judith Nies McFadden eds., 1970).

2. See Edith M. Lederer, Int'l Criminal Court Gets Started, AssoCIATED PRESS, Sept. 3, 2002. The "world's first permanent war crime tribunal" held its first meeting on September 3, 2002. Id.

3. The Rome Statute is the statute governing the International Criminal Court. See Rome Statute of the International Criminal Court, opened for signature July 17, 1998, 37 I.L.M. 999, art. 6 (1998) (entered into force July 1, 2002), available at http://www.un.org/law/icc/statute/ 99_corr/cstatute.htm (last visited Oct. 27, 2003) [hereinafter Rome Statute of the ICC].

4. See infra Part One II.

5. See Sheldon Glueck, The Nuremberg Trial aNd Aggressive War xi (1946).

6. Robert H. Jackson, J., Opening Speech of the Chief Prosecutor for the United States of America (Nov. 21, 1945), in TRIAL OF GERMAN MAJOR WAR CRIMINALS 3, 3 (William S. Hein \& Co., Inc. 2001) (1946).

7. The United Nations General Assembly includes delegations from member States of the United Nations who meet to "examin[e] [] international issues." See United Nations General Assembly, 57th Sess., available at http://www.un.org/ga/57/info.htm (last visited Oct. 27, 2003). 
international criminal court to deal with such atrocities in an international forum. ${ }^{8}$ Many years and many more atrocities later, the International Criminal Court is the culmination of those efforts. ${ }^{9}$

This Note will review the legal problems with the Nuremberg trials to discover whether those problems are rectified through the International Criminal Court. The Note is broken into two parts; Part One will focus on the ICC, while Part Two will focus on Nuremberg. Part One, Section I discusses, in some detail, the Rome Statute. Section II addresses the specific problems that the United States has stated as reasons for not signing the Treaty. Section III lists some other important issues that should be taken into account, with respect to the ICC, such as world views on the actions of the United States. Part Two reviews the Nuremberg trials with special emphasis on the legal problems faced during those trials. Finally, the Note will conclude comparing and contrasting Nuremberg and the ICC.

\section{PART ONE:THE INTERNATIONAL CRIMINAL COURT}

\section{THE INTERNATIONAL CRIMINAL COURT}

\section{A. Introduction ${ }^{10}$}

On September 3, 2002, the International Criminal Court (ICC) ${ }^{11}$ held its

8. COALITION For THE INT'L CRIMINAL COURT, QUESTIONS AND ANSWERS ON THE INTERNATIONAL CRIMINAL COURT (2002), at http://www.iccnow.org/documents/iccbasics/ Q\&AJuly2002.pdf (last visited Oct. 27, 2003).

9. Atrocities that have gone untried:

4 million people were murdered in Stalin's purges (1937 - 1953), 5 million were annihilated in China's Cultural Revolution (1966 - 1976), 2 million were butchered in Cambodia's killing fields (1975 - 1979), 30,000 disappeared in Argentina's Dirty War (1976 - 1983), 200,000 were massacred in East Timor (1975 - 1985), 750,000 were exterminated in Uganda (1971 - 1987), 100,000 Kurds were gassed in Iraq (1987 - 1988), and 75,000 peasants were slaughtered by death squads in El Salvador (1980 - 1992).

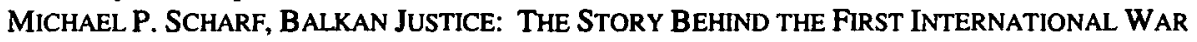
CRIMES TRIAL SINCE NUREMBERG xiii-xiv (1997).

In the past half-century alone, more than 250 conflicts have erupted around the world; more than 86 million civilians, mostly women and children died in these conflicts; and over 170 million people were stripped of their rights, property and dignity. Most of these victims have been simply forgotten and few perpetrators have been brought to justice.

COALTION FOR THE INT'L CRIMINAL COURT, supra note 8.

10. See lella Nadya Sadat, THE INTERnational Criminal Court and the TRANSFORMATION OF INTERNATIONAL LAW: JUSTICE FOR THE NEW MILLENNIUM 285-310 (2002), for an excellent overview of the court in chart format.

11. The International Criminal Court is distinguished from the International Court of Justice in that the International Court of Justice primarily handles disputes between states as opposed to acquiring jurisdiction over individuals. COALTION FOR THE INT'L CRIMINAL COURT, supra note 8. 
first meeting. ${ }^{12}$ The ICC is the first international effort to establish a permanent tribunal for prosecuting war crimes. ${ }^{13}$ The United States is not a participant in this effort. ${ }^{14}$ The Rome Statute (Statute) ${ }^{15}$ was opened for signatures on July $17,1998 .{ }^{16}$ On December 31, 2000, President Bill Clinton signed the Rome Statute. ${ }^{17}$ Participation in the ICC preparatory commission required signing the statute by that date. ${ }^{18}$ Thus, signing the statute made it possible for the United States to have influence over the court's procedures. ${ }^{19}$ On May 6, 2002, the Bush administration informed the United Nations Secretary General, Kofi Annan, that the United States would not ratify the Rome Statute. ${ }^{20}$ Thus, in essence, President Clinton's signature was rescinded. President Bush took this course of action under President Clinton's advice to the Bush administration that the Senate should not ratify the Rome Statute in its current state and that the United States should continue to address concerns through participation in the Preparatory Commission. ${ }^{21}$ The Rome Statute entered into force

12. Lederer, supra note 2.

13. Id.

14. Id. At this initial meeting, the Assembly of State Parties elected as president Prince Zeid bin Raad of Jordan. Id. The assembly also elected as vice presidents Ambassador Allieu Kanu of Sierra Leone and Ambassador Felipe Paolillo of Uruguay. Id. The United States seat was empty at this very important meeting. Id. By not ratifying the Rome Statute, the United States is not a State Party and has neither the authority to vote for or nominate officers of the ICC nor any influence in guiding the future of the court. See Lederer, supra note 2.

15. Mahnoush H. Arsanjani, Developments in International Criminal Law: The Rome Statute of the International Criminal Court, 93 AM. J. COMP. L. 22, 24-25. The Rome Statute contains three principles: 1) "the principle of complementarity," 2) that the International Criminal Court "deal[s] only with the most serious crimes of concern to the international community as a whole[,]" and 3) that the Statute "to the extent possible, remain within the realm of customary international law." Id. The author of this article is a Senior Legal Officer in the Office of Legal Affairs at the United Nations and served as the Secretary of the Committee of the Whole of the Rome Conference. Id. at 22.

16. See Rome Statute of the ICC, supra note 3, art. 125. Sixty states were needed to ratify the Statute, and thus the International Criminal Court. See id. art. 126. See generally Panel Discussion, Association of American Law Schools Panel on the International Criminal Court, 36 AM. CRIM. L. REV. 223 (1999) (discussing the establishment of the International Criminal Court) [hereinafter Panel Discussion].

17. Friends Committee on National Legislation, Status of the International Criminal Court: 2001 .

18. Id.

19. See id. President Clinton made it clear that he only signed the treaty so that the United States could still influence the ICC and that he would recommend to the next president not to send the treaty to the Senate for ratification until some of the "fundamental concerns" were addressed. Diane Marie Amann \& M.N.S. Sellers, The United States of America and the International Criminal Court, 50 AM. J. CoMP. L. 381 (2002). See also Fact Sheet, U.S. Dept. of State, The International Criminal Court (Aug. 2, 2002), at http://www.State.gov/t/pm/rls/ fs $/ 2002 / 23426 . h t m \# 2$ (last visited Oct. 27, 2003) [hereinafter U.S. Fact Sheet].

20. Secretariat of The Coalition for an International Criminal Court, Country-by-Country Ratification Status Report, Sept. 19, 2002, at http://www.icc.igc.org/countryinfo/theamericas/ unitedstates.html (last visited Oct. 3, 2003).

21. Id. 
on July $1,2002 .{ }^{22}$ As of this writing, 139 countries have signed the Rome Statute, with ninety-two countries officially ratifying it. ${ }^{23}$ The ICC is planning to start taking cases in $2003 .^{24}$

\section{A. The Make Up of the International Criminal Court}

The International Criminal Court has four organs: (1) The Presidency; (2) A Pre-trial Division; a Trial Division; and an Appeals Division (each having respective Chambers); (3) The Office of the Prosecutor; and (4) The Registry. ${ }^{25}$ All of the officials of the ICC must be fluent in one of the two working languages of the court, which are English and French. ${ }^{26}$

The President, a First Vice-President, and a Second Vice-President constitute the Presidency. ${ }^{27}$ The judges that form the Presidency serve the ICC full-time while the other judges serve full-time as the need arises. ${ }^{28}$ The PreTrial and the Trial Divisions have three judges each, while the Appeals Division is composed of four judges and the President. ${ }^{29}$

Any State Party, with each State Party having one nomination per election, may nominate Judges. ${ }^{30}$ Judges are to be "of high moral character, impartiality and integrity who possess the qualifications required in their respective States for appointment to the highest judicial offices." 31 The

22. The Coalition for an International Criminal Court, at http://www.icc.igc.org/ documents/iccbasics/history.pdf (last visited Oct. 3, 2003) [hereinafter CICC Home Page].

23. Id. The countries that have ratified the Rome Statute as of October 3, 2003 are: Afghanistan, Albania, Andorra, Antigua and Barbuda, Argentina, Australia, Austria, Barbados, Belgium, Belize, Benin, Bolivia, Bosnia and Herzegovina, Botswana, Brazil, Bulgaria, Cambodia, Canada, Central African Republic, Colombia, Costa Rica, Croatia, Cyprus, Democratic Republic of Congo, Denmark, Djibouti, Dominica, East Timor, Ecuador, Estonia, Fiji, Finland, France, Gabon, Gambia, Georgia, Germany, Ghana, Greece, Guinea, Honduras, Hungary, Iceland, Ireland, Italy, Jordan, Latvia, Lesotho, Liechtenstein, Lithuania, Luxembourg, Macedonia (F.Y.R.), Malawi, Mali, Malta, Marshall Islands, Mauritius, Mongolia, Namibia, Nauru, Netherlands, New Zealand, Niger, Nigeria, Norway, Panama, Paraguay, Peru, Poland, Portugal, Republic of Korea, Romania, Saint Vincent and the Grenadines, Samoa, San Marino, Senegal, Serbia and Montenegro, Sierra Leone, Slovakia, Slovenia, South Africa, Spain, Sweden, Switzerland, Tajikistan, Tanzania (United Rep.), Trinidad and Tobago, Uganda, United Kingdom, Uruguay, Venezuela, and Zambia. The Coalition for an International Criminal Court, Rome Statute Signature and Ratification Chart, at http://www.icc.igc.org/countryinfo/ worldsigsandratifications.html (last visited Oct. 3, 2003).

24. Lederer, supra note 2.

25. Rome Statute of the ICC, supra note 3, art. 34.

26. Id. art. 50(2). The ICC's judgments are to be published in the "official" languages of the ICC: Arabic, Chinese, English, French, Russian, and Spanish. Id. art. 50(1).

27. Id. art. 38(3). The judges elect all three positions by a majority vote. Id. art. 38(1). The term for all presidential positions is three years with eligibility for one re-election. Id. art. 38(1).

28. Rome Statute of the ICC, supra note 3, art. 35.

29. Id. art. 39(1)-(2).

30. Id. art. 36(4).

31. Id. art. 36(3)(a). 
Assembly of the States Parties (Assembly) elects judges by secret ballot. ${ }^{32}$ Two-thirds of the Assembly must be in attendance and voting; the judges receiving the highest number of votes are elected. ${ }^{33}$ "No two judges may be nationals of the same State." ${ }^{34}$ Judges are elected for a term of nine years and cannot be re-elected. ${ }^{35}$

The Office of the Prosecutor is considered to be independent of the ICC. ${ }^{36}$ The main function of the Prosecutor is to receive referrals for investigations and to determine whether enough evidence exists to pursue prosecution. ${ }^{37}$ High moral character, competency, experience in prosecuting criminal cases, and fluency in at least one of the ICC's languages are requirements for both the Prosecutor, as well as any Deputy Prosecutors. ${ }^{38}$ The members belonging to the Assembly of States Parties (Assembly) elect the Prosecutor by secret ballot; the Prosecutor, in turn, provides a list to the Assembly of potential Deputy Prosecutors. ${ }^{39}$ The Assembly then elects the Deputy Prosecutors in the same manner. ${ }^{40}$ Similar to the Judges, the Prosecutor and any Deputy Prosecutors have nine-year terms and may not be re-elected, although some exceptions exist to assist in the initial establishment of the ICC. ${ }^{41}$

The Registry has the responsibility of carrying out all of the non-judicial aspects of the ICC. ${ }^{42}$ The Registrar is the "principal administrative officer of

\section{Id. art. 36(6).}

33. Id.

34. Rome Statute of the ICC, supra note 3, art. 36(7). The State Parties should consider the following when electing judges: fair representation of the world's legal systems; fair representation geographically, and; "fair representation of female and male judges." Id. art. 36(8). State Parties should also consider legal expertise of the judges on specific issues "including, but not limited to, violence against women or children." Id.

35. Id. art. 36(9).

36. Id. art. 42(1). See also 1 The Rome StatuTE of THE INTERnATIONAL Criminal COURT 269 (Antonio Cassese et al. eds., 2002) [hereinafter THE ROME STATUTE]. (setting forth that the Office of the Prosecutor acts independently of the ICC). The Prosecutor having control over investigations was the most suspicious issue to the drafters of the statute. Id. at 1150 .

37. Rome Statute of the ICC, supra note 3, art. 42(1). The Office of the Prosecutor may have Deputy Prosecutors to assist the Prosecutor. Id. art. 42(2). All Deputy Prosecutors, as well as the Prosecutor, are to be of different nationalities. Id. See THE ROME STATUTE, supra note 36, at 270 (The Prosecutor has Deputy Prosecutors who hold the same powers as the Prosecutor, all must be of varying nationalities).

38. Rome Statute of the ICC, supra note 3, art. 42(3). See also THE ROME STATUTE, supra note 36, at 270.

39. Rome Statute of the ICC, supra note 3, art. 42(4).

40. Id. See The Rome STATUTE, supra note 36, at 270 ("The Prosecutor is elected by secret ballot by absolute majority of the members of the Assembly of State Parties, and Deputy Prosecutors are elected in the same way from a list provided by the Prosecutor.").

41. Rome Statute of the ICC, supra note 3, art. 42(4). See also THE ROME STATUTE, supra note 36, at 270 ("The Prosecutor and Deputy Prosecutors, like the judges, are not eligible for re-election, with the exception of those initially appointed for a term of three years or less.").

42. Rome Statute of the ICC, supra note 3, art. 43(1). See also THE ROME STATUTE, supra note 36 , at 276 (stating that the registry is responsible for administering the ICC). 
the Court" and is supervised by the President of the ICC. ${ }^{43}$ The Registrar is to have "high moral character, be highly competent" and be fluent in at least one of the ICC's working languages. ${ }^{44}$ The judges take recommendations from the Assembly and elect, by secret ballot, the Registrar and, if needed, a Deputy Registrar. ${ }^{45}$ The Registrar's term is for five years with the option of one re-election. ${ }^{46}$

\section{B. Jurisdiction of the International Criminal Court}

The International Criminal Court is limited to four groups of crimes: ${ }^{47}$ genocide, ${ }^{48}$ crimes against humanity, ${ }^{49}$ war crimes, ${ }^{50}$ and

43. Rome Statute of the ICC, supra note 3, art. 43(2); see also THE ROME STATUTE, supra note 36 , at 277 .

44. Rome Statute of the ICC, supra note 3, art. 43(3). See also THE ROME STATUTE, supra note 36, at 277.

45. Rome Statute of the ICC, supra note 3, art. 43(4).

46. Id. art. 43(5). See also THE ROME STATUTE, supra note 36, at 277.

47. See Rome Statute of the ICC, supra note 3, art. 5. See Report of the Preparatory Commission for the International Criminal Court, U.N. Preparatory Commission for the International Criminal Court, Finalized Draft Text of the Elements of Crimes (Nov. 2, 2000), U.N. Doc. PCNICC/2000/1/Add.2, for a list of proposed Elements of Crimes.

48. Rome Statute of the ICC, supra note 3, art. 5. Genocide is defined as:

[A]ny of the following acts committed with intent to destroy, in whole or in part, a national, ethnical, racial or religious group, as such: (a) Killing members of the group; (b) Causing serious bodily or mental harm to members of the group; (c) Deliberately inflicting on the group conditions of life calculated to bring about its physical destruction in whole or in part; (d) Imposing measures intended to prevent births within the group; (e) Forcibly transferring children of the group to another group.

Id. art. 6. This definition "tracks the Genocide Convention" definition of genocide. Panel Discussion, supra note 16, at 245. See Arsanjani, supra note 15, at 30.

49. Rome Statute of the ICC, supra note 3, art. 5. Crimes against humanity is defined as:

[A]ny of the following acts when committed as part of a widespread or systematic attack directed against any civilian population, with the knowledge of the attack: (a) Murder; (b) Extermination; (c) Enslavement; (d) Deportation or forcible transfer of population; (e) Imprisonment or other severe deprivation of physical liberty in violation of fundamental rules of international law; (f) torture; (g) Rape, sexual slavery, enforced prostitution, forced pregnancy, enforced sterilization, or any other form of sexual violence of comparable gravity; (h) Persecution against any identifiable group or collectivity on political, racial, national, ethnic, cultural, religious, gender as defined in paragraph 3 , or other grounds that are universally recognized as impermissible under international law, in connection with any act referred to in this paragraph or any crime within the jurisdiction of the Court; (i) Enforced disappearance of persons; (j) The crime of apartheid; (k) Other inhumane acts of a similar character intentionally causing great suffering, or serious injury to body or to mental or physical health.

Id. art. 7(1). Article 7(2) goes on to define many of the terms used in article 7(1). Id. art 7(1). This definition "goes beyond Nuremberg and other previous definitions" by adding, for example, "systematic torture, rape, and forced disappearances." Panel Discussion, supra note 16, at 245 . See Arsanjani, supra note 15 , at $30-31$, for a historical look at the discussions that 
aggression. $^{51}$ For the ICC to exercise jurisdiction in these matters, the precondition of jurisdiction must be satisfied. ${ }^{52}$ A precondition is that the matter involves a State Party. ${ }^{53}$ When a State ratifies the Rome Statute, that State automatically submits itself and its citizens to the jurisdiction of the ICC. ${ }^{54}$ The ICC has jurisdiction if the State is a State Party and 1) the crime was committed on that State's territory $;^{55}$ or 2 ) the State is the State of "which

took place regarding the definition of crimes against humanity.

50. Rome Statute of the ICC, supra note 3, art. 5. War crimes is defined as:

(a) Grave breaches of the Geneva Conventions of 12 August 1949, namely, any of the following acts against persons or property protected under the provisions of the relevant Geneva Convention: (i) Wilful killing; (ii) Torture or inhuman treatment, including biological experiments; (iii) willfully causing great suffering, or serious injury to body or health; (iv) Extensive destruction and appropriation of property, not justified by military necessity and carried out unlawfully and wantonly; (v) compelling a prisoner of war or other protected person to serve in the forces of a hostile Power; (vi) Wilfully depriving a prisoner of war or other protected person of the rights of fair and regular trial; (vii) Unlawful deportation or transfer of unlawful confinement; (viii) Taking of hostages.

Id. art. 8(2)(a). Article 8 goes on to define in great detail other serious violations that would constitute war crimes within the meaning of the statute. Id. art. 8(b). This definition is "largely drawn from the Hague Rules, the Geneva Conventions, the Geneva Protocol II, and so forth, but with controversial additions like ... prohibiting an occupying power from transferring its own people into the occupied territory." Panel Discussion, supra note 16, at 245.

51. Rome Statute of the ICC, supra note 3, art. 5. The crime of aggression is not yet defined; it will come into effect once it is defined. Id. art. $5(2)$. Other crimes that were discussed but not added to the ICC's jurisdiction are: drug crimes, international terrorism, mercenarism, and willful and sever damage to the environment. THE ROME STATUTE, supra note 36, at 497. Professor Halberstam of Benjamin N. Cardozo School of Law, who has "long supported establishing an International Criminal Court[,]" thinks that the definitions of crimes are "both too broad and too narrow" in that, on one hand, the Statute does not include some crimes that have previously been defined and agreed to by many states, and, on the other hand, the Statute redefines crimes that have established, agreed upon definitions while adding the crime of aggression, to which no one can agree on a definition. Panel Discussion, supra note 16 , at 247. See Arsanjani, supra note 15 , at 30 , for a discussion regarding the negotiations of the definition of the crime of aggression.

52. See THE Rome STATUTE, supra note 36, at 214. Article 12(2) of the Rome Statute gives the ICC jurisdiction over states that have "a special link" to one of the crimes enumerated in Article 5. Id. A special link is created when the nationality of the person who committed the crime is from that State or when the crime is committed in that State. Id. However, any action of the ICC upon non-member states must have consent of the State involved. Id.

53. Rome Statute of the ICC, supra note 3, art. 12. A State Party is any State that accedes to the Rome Statute. See id. art. 125.

54. Id. art. 12(1).

55. This jurisdiction is regardless of the nationality of the accused; thus, if an American is charged with a crime on the territory of a State Party, the ICC would have jurisdiction over the accused American. See THE ROME STATUTE, supra note 36, at 562. This is the reason behind the United States actively seeking bilateral agreements with State Parties to immunize Americans from jurisdiction of the ICC. See infra Part One III.A. 
the person accused of the crime is a national." 56 Finally, a State can voluntarily accept the jurisdiction of the ICC if the State is not a State Party to the Rome Statute. ${ }^{57}$ Thus, the ICC will typically not have jurisdiction over crimes committed on the territory of non-State Parties, by non-State Party nationals, unless the State of the accused submits to ICC jurisdiction. ${ }^{58}$ Nevertheless, the Security Council ${ }^{59}$ can adopt legislation through the United Nations Charter, Chapter VII, which will enable the ICC to exercise jurisdiction even in those cases where none of the circumstances involve a State Party. ${ }^{60}$ This action would be similar to the ad hoc tribunals of Rwanda ${ }^{61}$ and Yugoslavia. ${ }^{62}$

Once a precondition of jurisdiction is satisfied, the ICC can exercise jurisdiction through any of three possible referrals. ${ }^{63}$ Referrals may come from a State Party, the United Nations Security Council, or the ICC Prosecutor $^{64}$ may initiate a proceeding. ${ }^{65}$ Once a referral has been received, the Prosecutor will perform an initial examination to determine if there is sufficient evidence to go forward. ${ }^{66}$ The ICC can only prosecute crimes that occur after July $1,2002 .{ }^{67}$

56. Rome Statute of the ICC, supra note 3, art. 12(2). For example,

if State A is the State of nationality of a person accused of one of the crimes listed in Article 5 and this State is Party to the Rome Statute, the ICC has jurisdiction over that person, and can exercise its functions on the territory of State A. The [ICC], however, can also exercise its functions and powers on the territory of State B, Party to the Statute, though this State has no 'jurisdictional link' with the crime. This would occur, if, for instance, a witness is a national or resident of State B and is summoned to appear before the Court.

THE ROME STATUTE, supra note 36, at 214.

57. Rome Statute of the ICC, supra note 3, art. 12(3).

58. See THE ROME STATUTE, supra note 36, at 563.

59. See infra Part One I.D., for information on the power of the Security Council.

60. See id. at 563. See also Arsanjani, supra note 15, at 26 (stating that the requirement of consent of jurisdiction does not apply if the case is referred by the Security Council).

61. See United Nations, International Criminal Tribunal for Rwanda, at http://www.ictr.org (last visited Oct. 27, 2003), for information regarding the International Tribunal for Rwanda, including a daily update.

62. See United Nations, International Criminal Tribunal for the Former Yugoslavia, at http://www.un.org/icty (last visited Oct. 27, 2003), for information regarding the International Criminal Tribunal for the Former Yugoslavia.

63. Rome Statute of the ICC, supra note 3, art. 13. A referral denotes when "[a] situation in which one or more [of the crime of genocide, crimes against humanity, war crimes, or the crime of aggression] appears to have been committed is referred to the Prosecutor." See id.

64. See infra Part One I-D.

65. Rome Statute of the ICC, supra note 3, art. 13. See THE ROME STATUTE, supra note 36, at 1144-45 (describing the three referral sources from which the Prosecutor can investigate potential defendants: (1) The Security Council itself; (2) a State Party; (3) any other source or through the Prosecutor alone).

66. Rome Statute of the ICC, supra note 3, art. 15(3).

67. See id. art. 11(1). As more states ratify the Rome Statute, the ICC will have jurisdiction over crimes committed after the Rome Statute is in force. Id. art. 11(2). 
There is an additional obligation of the ICC to "defer to a national investigation." 68 Once it is determined that an investigation is necessary, "the Prosecutor shall notify all States Parties and those States which, taking into account the information available, would normally exercise jurisdiction over the crimes concerned." ${ }^{\prime 9}$ If, within one month of receiving notice regarding an investigation, a State informs the ICC that the State is investigating either its own nationals, or other nationals, within its jurisdiction, the State may request that the Prosecutor defer to the State's investigation. ${ }^{70}$ However, the Prosecutor has the option of applying to the Pre-Trial Chamber ${ }^{71}$ to authorize an investigation by the Prosecutor, disregarding the request of the State, as long as the Prosecutor can show a State's "unwillingness" and/or "inability" to investigate. ${ }^{72}$ Either the Prosecutor or the State may appeal the decision of the Pre-Trial Chamber. ${ }^{73}$ Additionally, the Prosecutor may review the deferral up to six-months after the deferral date "or at any time when there has been a significant change of circumstances based on the State's unwillingness or inability genuinely to carry out an investigation." 74 Notification is unnecessary if the referral was initiated via the Security Council. ${ }^{75}$ Therefore, it is implied that the ICC will not defer to a national investigation upon the Security Council's referral of a case.

68. THE ROME STATUTE, supra note 36 , at 1141-42.

69. Rome Statute of the ICC, supra note 3, art. 18(1). See also THE ROME STATUTE, supra note 36, at 1162 (explaining that the Prosecutor is responsible for notifying all State Parties and any States that are capable of exercising jurisdiction over the accused of the ensuing investigation to enable a national investigation if the State would like to pursue one).

70. Rome Statute of the ICC, supra note 3, art. 18(2).

71. See infra Part One I.E.

72. Rome Statute of the ICC, supra note 3, art. 17(2), 18(3). See THE ROME STATUTE, supra note 36, at 1163 . To determine the "unwillingness" of a State to investigate or prosecute a crime,

the Court shall consider . . . whether one or more of the following exist, as applicable: (a) The proceedings were or are being undertaken or the national decision was made for the purpose of shielding the person concerned from criminal responsibility for crimes with the jurisdiction of the Court referred to in article 5; (b) There has been an unjustified delay in the proceedings which in the circumstances is inconsistent with an intent to bring the person concerned to justice; (c) The proceedings were not or are not being conducted independently or impartially, and they were or are being conducted in a manner which, in the circumstances, is inconsistent with an intent to bring the person concerned to justice.

Rome Statute of the ICC, supra note 3, art. 17(2). On the other hand, to determine if a State is "unable" to properly investigate or prosecute a crime, "the Court shall consider whether, due to a total or substantial collapse or unavailability of its national judicial system, the State is unable to obtain the accused or the necessary evidence and testimony or otherwise unable to carry out its proceedings." Id. art. 17(3).

73. Rome Statute of the ICC, supra note 3, art. 18(4).

74. Id. art. 18(3).

75. See Rome Statute of the ICC, supra note 3, art. 18(1). 


\section{The Office of the Prosecutor}

Once a referral has been received, the Prosecutor must conduct a preliminary examination of the evidence and evaluate the information available to determine whether reasonable grounds exist to initiate an investigation. ${ }^{76}$ The preliminary examination determines whether there is a "serious and sufficient basis for an investigation to be initiated."77 If the Prosecutor determines that there is adequate evidence to pursue an investigation, the Prosecutor must receive authorization from the Pre-Trial Chamber to proceed. ${ }^{78}$ The Prosecutor must notify the Pre-Trial Chamber of a decision not to investigate only if the Prosecutor's opinion rested solely on the basis that an investigation would not serve justice. ${ }^{79}$ If the Prosecutor does an investigation, once the investigation is complete, the Prosecutor must determine if the evidence is sufficient for prosecution. ${ }^{80}$ If the Prosecutor determines there is not enough evidence to prosecute, the Prosecutor must then notify the Pre-Trial Chamber, as well as whoever referred the case to the $\mathrm{ICC}{ }^{81}$ Under either circumstance, upon request of the party referring the incident, "the Pre-Trial Chamber may review a decision of the Prosecutor."82 Anytime that the Prosecutor decides not to pursue a referral, either at the investigation stage or the prosecution stage, due to the pursuit not being "in the interests of justice," the decision is "effective only if confirmed by the Pre-Trial Chamber." ${ }^{83}$ Upon receiving new facts or information, the Prosecutor is authorized to re-open the referral for either investigation or prosecution. ${ }^{84}$

While the Prosecutor has immense power in determining whether to investigate and prosecute, the Statute heavily regulates that power. ${ }^{85}$ The Prosecutor is doubtlessly accountable to the Assembly because the Assembly elects the Prosecutor. ${ }^{86}$ Additionally, the Prosecutor has to receive authorization from the Pre-Trial Chamber to open an investigation. ${ }^{87}$ The Prosecutor is obligated to defer to the national investigation if so requested, although the Pre-Trial Chamber's ability to trump that investigation may diminish the

76. Id. art. 53(1). See THE ROME STATUTE, supra note 36, at 269. The responsibilities of the Office of the Prosecutor are to receive referrals, investigate, and, when appropriate, prosecute the crimes within the Court's jurisdiction. Id. The Prosecutor must conduct a preliminary examination of all cases referred before an investigation is initiated. Id. at 1146

77. Id. at 1146. See Rome Statute of the ICC, supra note 3, art. 54, for a list of "[d]uties and powers of the Prosecutor with respect to investigations."

78. See id. art. 53(3).

79. See id. art. 53(1).

80. THE ROME STATUTE, supra note 36 , at 1171.

81. Rome Statute of the ICC, supra note 3, art. 53(2).

82. Id. art. 53(3).

83. Id. art. 53(3).

84. Id. art. 53(4). See THE ROME STATUTE, supra note 36, at 1215.

85. Id. at 1138.

86. Id. at 1140.

87. Id. at 1141 . 
effect of this safeguard. ${ }^{88}$ More importantly, the Security Council is given the deferral power for any investigation or prosecution conducted by the ICC through a resolution under Chapter VII of the Charter of the United Nations. ${ }^{89}$ Once the Security Council has deferred an investigation, there is a twelvemonth waiting period before the investigation or prosecution can proceed. ${ }^{90}$ This deferral power may be renewed endlessly in the same fashion. ${ }^{91}$

The Security Council is made up of fifteen members, five of which are permanent while the other ten rotate for a two-year period after being elected by the General Assembly. ${ }^{92}$ Since the United States is a permanent member of the Security Council and has veto power, it can greatly influence the initiation and deferral of investigations and prosecutions. ${ }^{93}$ Any votes on "substantive matters" require that all five of the permanent members agree, which provides the five members veto power. ${ }^{94}$ Any vote regarding an investigation or prosecution is a substantive matter; all other votes are for "procedural matters" and only require nine out of the fifteen members to agree. ${ }^{95}$ Thus, because the Security Council may refer a case to the Prosecutor, and has deferral power over investigations and prosecutions, the United States, even though not a member of the ICC, has influential power over it.

88. Id. at 1141-42.

89. Rome Statute of the ICC, supra note 3, art. 16; THE ROME STATUTE, supra note 36, at 1141 . It should be noted that Article 16 contains only this provision making it seemingly quite important. The full text of Article 16 states:

No investigation or prosecution may be commenced or proceeded with under this

Statute for a period of 12 months after the Security Council, in a resolution adopted under Chapter VII of the Charter of the United Nations, has requested the Court to that effect; that request may be renewed by the Council under the same conditions.

Rome Statute of the ICC, supra note 3, art. 16. See CHARTER OF THE UNITED NATIONS Ch. VII, available at http://www.un.org/aboutun/charter/index.html (last visited Oct. 27, 2003) (Chapter VII is titled 'Action with Respect to Threats to the Peace, Breaches of the Peace, and Acts of Aggression'); Arsanjani, supra note 15, at 26-27.

90. Rome Statute of the ICC, supra note 3, art. 16, for a historical look at the compromise reached regarding this article.

91. Id.

92. See Security Council Home Page, available at http://www.un.org/Docs/sc (last visited Oct. 27, 2003) [hereinafter Security Council] The five permanent members are: China, France, Russia Federation, United Kingdom, and the United States. Id. The current ten rotating members are: Angola, Bulgaria, Cameroon, Chile, Colombia, Germany, Guinea, Mexico, Pakistan, Spain, Syrian and Arab Republic. Id.

93. See id. See generally Amann \& Sellers, supra note 19, at 386-88 (discussing the relationship between the Security Council, the United States, and the ICC).

94. Security Council, supra note 92. It is this veto power that makes the Security Council inadequate as the law dispensing body of the international community. See THE ROME STATUTE OF THE INTERNATIONAL CRIMINAL CouRT (Mauro Politi \& Giuseppe Nesi eds., 2001).

95. Security Council, supra note 92. 


\section{Pre-Trial Chamber}

A majority vote from the three judges sitting on the Pre-Trial Chamber is required for most decisions that the Prosecutor is involved in, including decisions of admissibility. ${ }^{96}$ Once the prosecutor has presented evidence from the preliminary inquiry, the Pre-Trial Chamber must believe that there is a "reasonable basis to proceed" before giving the Prosecutor permission to initiate an investigation. ${ }^{97}$ The Pre-Trial Chamber determines whether the ICC has jurisdiction over the case as well. ${ }^{98}$

The Pre-Trial Chamber is responsible for issuing warrants at the Prosecutor's request. ${ }^{99}$ In order to issue a warrant for arrest, the Pre-Trial Chamber must be satisfied that the evidence reasonably shows that the accused committed one of the enumerated crimes, ${ }^{100}$ that the ICC has jurisdiction, and that the arrest is necessary to make sure that the accused appears in court or does not obstruct justice by jeopardizing an investigation. ${ }^{101}$ A warrant may also be issued as a preventative measure if the ICC determines that the crime, or a related crime, is still in commission. ${ }^{102}$

The Pre-Trial Chamber is responsible for assisting the accused in the preparation of a defense. ${ }^{103}$ Additionally, the Chamber's responsibilities include "the protection and privacy of victims and witnesses, the preservation of evidence, the protection of persons who have been arrested or appeared in

96. See Rome Statute of the ICC, supra note 3, art. 57(2). A single judge sitting on the Pre-Trial Chamber has the authority to review the decision of the Prosecutor not to proceed with an investigation after the Prosecutor's preliminary inquiry. THE ROME STATUTE, supra note 36, at 1217. It takes a majority vote of the Pre-Trial Chamber to order the Prosecutor to investigate. Id.

97. Id. at 1215.

98. Id.

99. Rome Statute of the ICC, supra note 3, art. 57(3). The Prosecutor's application for a warrant must contain:

(a) The name of the person and any other relevant identifying information; (b) A specific reference to the crimes within the jurisdiction of the Court which the person is alleged to have committed; (c) A concise statement of the facts which are alleged to constitute those crimes; (d) A summary of the evidence and any other information which establish reasonable grounds to believe that the person committed those crimes; and (e) The reason why the Prosecutor believes that the arrest of the person is necessary.

Id. art. 58(2).

100. See supra note 47-51.

101. Rome Statute of the ICC, supra note 3, art. 58(1). The actual warrant for arrest must contain the following information: "(a) The name of the person and any other relevant identifying information; (b) A specific reference to the crimes within the jurisdiction of the Court for which the person's arrest is sought; and (c) A concise statement of the facts which are alleged to constitute those crimes." Id. art. 58(3).

102. Id. art. 58(1)(b)(iii).

103. $I$ d. art. $57(3)(\mathrm{b})$. 
response to a summons, and the protection of national security information." 104

If the Pre-Trial Chamber determines that a State Party's judicial system has collapsed, and therefore, the State Party cannot authorize the Prosecutor to investigate on the State's territory, the Pre-Trial Chamber may authorize that the Prosecutor carry on an investigation. ${ }^{105}$

The Pre-Trial Chamber performs a confirmation process where the charges are heard before the ICC, and the accused has an opportunity to "object to the charges ... [c]hallenge the evidence presented by the Prosecutor;" and the accused may present evidence in his defense. ${ }^{106}$ After the hearing, the Pre-Trial Chamber may either confirm the charges, decide that there is insufficient evidence to proceed, or adjourn the hearing until the Prosecutor either provides more evidence or amends the charges. ${ }^{107}$ If the charges are confirmed, the Presidency will order a Trial Chamber to conduct the trial. ${ }^{108}$

\section{E. The Trial Chamber}

The trial is held at the seat of the ICC, currently The Hague in the Netherlands. ${ }^{109}$ There can be no trials in absentia; the defendant's presence is required. ${ }^{110}$ Although, if the defendant becomes disruptive to the trial, alternative means for the defendant to participate may become necessary, such as observing the trial outside of the courtroom. ${ }^{111}$

The Trial Chamber is charged with assuring that the trial is "fair and expeditious and is conducted with full respect for the rights of the accused and due regard for the protection of victims and witnesses." 112 The trial is to be public, although certain proceedings may be closed as the Trial Chamber sees fit. ${ }^{113}$ The Trial Chamber will hear the plea of the accused after reading the charges that the Pre-Trial Chamber confirmed. ${ }^{114}$ All defendants are presumed innocent until proven guilty beyond a reasonable doubt. ${ }^{115}$ It is also the

104. Id. art. $57(3)(c)$.

105. Id. art. 57(3)(d).

106. Rome Statute of the ICC, supra note 3, art. 61(6).

107. Id. art. 61(7).

108. Id. art. 61(11).

109. Id. art. 62; see art. 3(1).

110. Id. art. 63(1).

111. Rome Statute of the ICC, supra note 3, art. 63(2).

112. Id. art. 64(2).

113. Id. art 64(7). Proceedings may be closed to "protect confidential or sensitive information to be given in evidence[,]" or for the protection of victims and witnesses as set forth in article 68. See id. See also id. art. 68.

114. Id. art 64(8).

115. Rome Statute of the ICC, supra note 3, art. 66. 
responsibility of the Trial Chamber to make sure that the trial is accurately recorded and maintained by the Registrar. ${ }^{116}$

\section{G. Rights of the Accused}

The accused has the right to a public, fair, and impartial hearing. ${ }^{117}$ Additionally, the defendant has the following minimum guarantees:

(a) To be informed promptly and in detail of the nature, cause and content of the charge, in a language which the accused fully understands and speaks; (b) To have adequate time and facilities for the preparation of the defence and to communicate freely with counsel of the accused's choosing in confidence; (c) To be tried without undue delay; (d) Subject to [the defendant not disrupting the court], to be present at the trial, to conduct the defence in person or through legal assistance of the accused's choosing, to be informed, if the accused does not have legal assistance, of this right and to have legal assistance assigned by the Court in any case where the interests of justice so require, and without payment if the accused lacks sufficient means to pay for it; (e) To examine, or have examined, the witnesses against him or her and to obtain the attendance and examination of witnesses on his or her behalf under the same conditions as witnesses against him or her. The accused shall also be entitled to raise defences and to present other evidence admissible under this Statute; (f) To have, free of any cost, the assistance of a competent interpreter and such translations as are necessary to meet the requirements of fairness, if any of the proceedings of or documents presented to the Court are not in a language which the accused fully understands and speaks; (g) Not to be compelled to testify or to confess guilt and to remain silent, without such silence being a consideration in the determination of guilt or innocence; (h) To make an unsworn oral or written statement in his or her defence; and (i) Not to have imposed on him or her any reversal of the burden of proof or any onus of rebuttal. ${ }^{118}$

116. Id. art. 64(10).

117. Id. art. 67(1).

118. Id. art. 67. Professor Blakesley of Louisiana State University Law Center notes that there is "nothing at all in the Statute relating to what we in the United States would consider Fourth Amendment interests." Panel Discussion, supra note 16, at 237. The Fourth Amendment provides:

The right of the people to be secure in their persons, houses, papers and effects, 
The rights that a defendant of the ICC and a defendant in an American criminal court share are: a presumption of innocence; the proof standard of "beyond reasonable doubt"; a right to bail; the right to a "fair, impartial, speedy, and public hearing"; and the right to remain silent without the silence being used to as a factor in determining the verdict. ${ }^{119}$ One of the most noticeable and important differences between the ICC and American criminal courts is that defendants in the ICC do not have a right to a jury trial, which is a right guaranteed to Americans by the United States Constitution. ${ }^{120}$ Further, the ICC Prosecutor is able to appeal a verdict, while the Constitution protects people from being tried for the same crime twice. ${ }^{12}$ Finally, the United States Constitution guarantees the right of the defendant to face witnesses, whereas witnesses in the ICC may be absent and anonymous. ${ }^{122}$

On the other hand, the ICC provides more protection to suspects. Suspects are given Miranda type warnings prior to their questioning as opposed to prior to their arrest as the rights afforded American defendants stipulate. ${ }^{123}$ Furthermore, the Prosecutor of the ICC must reveal to the defense all evidence that tends to show that the accused is innocent, evidence that mitigates the guilt of the accused, or evidence that renders the prosecution's evidence questionable. ${ }^{124}$

against unreasonable searches and seizures, shall not be violated, and no warrants shall issue, but upon probable cause, supported by Oath or affirmation, and particularly describing the place to be searched, and the persons or things to be seized.

U.S. CONST. amend. IV. See Amann \& Sellers, supra note 19, at 396 ("The ICC Statute omits a hallmark of U.S. criminal litigation, the protection against unreasonable searches and seizures.").

119. Amann \& Sellers, supra note 19, at 395-96.

120. Id. at 396-97. See U.S. CONST. amend. VI; USA for the International Criminal Court, Get the Facts: America and the ICC, at http://www.usaforicc.org/facts_america-icc.html\# (last visited Oct. 10,2003) (comparing the language of the Rome Statute and the language of the U.S. Constitution). Note that the comparisons only include the comparative language and do not go further to include the language of the Rome Statute that negates some of the constitutionally protected rights of Americans such as article 69(2), which states that witnesses are to testify in person "except to the extent provided by the measures set forth in article 68[,]"; thus, undermining the constitutional right to be confronted with adverse witnesses. See Rome Statute of the ICC, supra note 3, art. 69(2); U.S. CONST. amend. VI.

121. Amann \& Sellers, supra note 19, at 397. See U.S. ConST. amend. V.

122. U.S. CoNST. amend. V; Rome Statute of the ICC, supra note 3, art. 68-69.

123. Rome Statute of the ICC, supra note 3, art. 55(2). See Miranda v. Arizona, 384 U.S. 436,444 (1966) (holding that the prosecution cannot use statements of the suspect that came after the suspect "has been taken into custody or otherwise deprived of his freedom of action in a significant way," without first warning the suspect of the privilege against selfincrimination); see also Amann \& Sellers, supra note 19, at 395.

124. Rome Statute of the ICC, supra note 3, art. 67(2). 


\section{H. Sentencing}

The ICC does not utilize the death penalty. ${ }^{125}$ Instead, the standard penalty is imprisonment for a maximum of thirty years, although the ICC may impose a life sentence "when justified by the extreme gravity of the crime and the individual circumstances of the convicted person." 126 The prison sentence will be served in a prison of a State chosen from a list of willing States based on: sharing responsibility between the States Parties, treatment of prisoners, the convicted person's view and nationality, and any other appropriate factors. ${ }^{127}$ If no State satisfies the requirements of the ICC, the host State (currently The Hague) will provide a prison facility. ${ }^{128}$ Every convicted person is entitled to a review to determine a reduction in sentence when twothirds of the sentence has been served, or after twenty-five years if the term is life imprisonment. ${ }^{129}$

\section{Appeals Process}

Either the Prosecutor or the defendant may request an appeal on the grounds of procedural error, error of fact, error of law, or "[a]ny other ground that affects the fairness or reliability of the proceedings or decision." ${ }^{130}$ Either party may also appeal the sentence of the defendant. ${ }^{131}$ The Appeals Chamber works in the same manner and with the same powers as the Trial Chamber. ${ }^{132}$ The Appeals Chamber may reverse a decision, amend a decision, or call for a new trial under a different Trial Chamber. ${ }^{133}$ If the Appeals Chamber has a question regarding a factual issue, the issue may be remanded to the original Trial Chamber for resolution, or the Appeals Chamber may request evidence

125. See id. art. 77(1). Professor Koenig of the Thomas M. Cooley Law School considers the death penalty system in the United States to be one of the worst in the world. See Panel Discussion, supra note 16, at 239. Professor Koenig worked on eliminating the death penalty from the Rome Statute and says that this Statute "offers much more protection for defendants than is offered most defendants in the United States." Id. at 240.

126. Rome Statute of the ICC, supra note 3, art. 77(1). Sentencing gave rise to debate because a lot of countries' Constitutions prohibit life imprisonment. See Sadat, supra note 10, at 165,167 . Additionally, because the ICC is only supposed to hear cases of the "most serious crimes[,]" one might think that all the crimes should be either of "extreme gravity" or not within the ICC's jurisdiction to sentence. See Rome Statute of the ICC, supra note 3, art. 5(1).

127. Rome Statute of the ICC, supra note 3, art. 103(3).

128. Id. art. 103(4).

129. Id. art. 110(3).

130. Id. art. 81(1).

131. Id. art. 81(2).

132. Rome Statute of the ICC, supra note 3, art. 83(1).

133. Id. art. 83(2). 
regarding the issue and make the determination sua sponte. ${ }^{134}$ The judgment of the Appeals Chamber is made by a majority of the ICC. ${ }^{135}$

\section{ISSUES THE UNTTED STATES HAS WITH THE INTERNATIONAL CRIMINAL COURT}

\section{A. Introduction}

Although the United States, in the past, has agreed with the ad hoc tribunals such as Nuremberg, Japan, Rwanda, and Yugoslavia, and has consistently agreed that a need for a permanent international criminal court exits, there has been much resistance to the current International Criminal Court. ${ }^{136}$ There are many opinions as to why the United States refuses to join in the efforts of the ICC, ${ }^{137}$ but, on May 6, 2002, when the United States officially withdrew from the Rome Statute, the U.S. Department of State issued a Fact Sheet listing the specific problems that the United States has with the ICC, which include: Jurisdiction; New Crimes; Aggression; the Prosecutor; Reservations; and Complementarity. ${ }^{138}$

\section{Jurisdiction}

The United States takes issue with article 12 of the Rome Statute, ${ }^{139}$ which gives the ICC jurisdiction over nationals from a non-party when crimes covered by the Statute are committed in the territory of a State Party. ${ }^{140}$ This gives the ICC jurisdiction over U.S. military personnel working in State Party territory even though the United States is not a party to the ICC. ${ }^{141}$ Another concern for some, although not specifically listed in the Fact Sheet, is that the

134. Id. art. 83(2).

135. Id. art. 83(4).

136. See AMERICAN BAR ASSOCIATION, Recommendation That the United States Government Accede to the Rome Statute of the International Criminal Court, at 4, Feb. 19, 2001 [hereinafter ABA RECOMMENDATION]. Of the voting nations, the United States, along with China, Iran, Iraq, Israel, Libya, and Sudan are the only nations to vote against the Rome Statute. See id.

137. See supra Part One III.B-C.

138. U.S. Fact Sheet, supra note 19.

139. Rome Statute of the ICC, supra note 3, art. 12.

140. Id. art. 12(2)(a). Professor Wise, Director of the Comparative Criminal Law Project at Wayne State University Law School states that the idea of a national from a non-party State falling under the jurisdiction of the ICC as "positively pernicious." Panel Discussion, supra note 16, at 230. Professor Wise, comparing the "democratic deficit" of the ICC with the "democratic deficit" of the Security Council, contends that, even though it takes two-thirds of the State Parties to amend the Statute, the ICC is still not a democratic institution when looking at the states comprising the two-thirds. Id.

141. U.S. Fact Sheet, supra note 138. See Rome Statute of the ICC, supra note 3, art. $12(2)$. 
ICC gives no protection to Heads of State ${ }^{142}$ and provides no domestic grant of amnesty. ${ }^{143}$

\section{New Crimes}

Under article 121 of the Rome Statute, State Parties can "opt out" of amendments to the Statute, including amendments for new crimes. ${ }^{144}$ If a State Party chooses not to accept the amendment, the ICC will not exercise jurisdiction over the State Party's nationals or on the State Party's territory when the crimes involved fall under ICC jurisdiction solely due to a violation of that particular amendment. ${ }^{145}$ A non-party is not offered the opportunity to opt-out of any amendments to the Rome Statute. ${ }^{146}$ Essentially, this means that if both an American and a State Party national commit a crime, which falls under the ICC jurisdiction through an amendment, and the crime is committed on another State Party's territory, the American could be prosecuted under the ICC, yet the State Party national would not if that country had opted-out of the amendment. The United States finds this double standard completely unacceptable. ${ }^{147}$

\section{Aggression}

The crime of aggression ${ }^{148}$ is included in the enumerated crimes under the ICC's jurisdiction, but the Rome Statute does not include a definition of the crime. ${ }^{149}$ Article 5(2) states that " $\left.t\right]$ he Court shall exercise jurisdiction over the crime of aggression once a provision is adopted [by amendment] defining the crime and setting out the conditions under which the Court shall

142. See Rome Statute of the ICC, supra note 3, art. 27 (specifically denying any relevance to "official capacity").

143. See Amann \& Sellers, supra note 19, at 392-95. See also Rome Statute of the ICC, supra note 3, art. 27; AMERICAN BAR ASSOCIATION RECOMMENDATION, supra note 136, at 6 (stating that the ICC exercising jurisdiction over officials is consistent with Nuremberg principles); Reuters, U.S. Fears Prosecution of President in World Court (Nov. 15, 2002) (discussing a senior United States official's comments regarding concerns over presidential and military leader prosecutions in "legitimate but controversial uses of force to protect world peace.”). But see Reuters, Report: U.S. Readies War Crimes Charges for Saddam (Oct. 30, 2002) (discussing United States plans to bring war crimes charges against Saddam Hussein, President of Iraq).

144. See Rome Statute of the ICC, supra note 3, art. 121(5).

145. Id.

146. U.S. Fact Sheet, supra note 138.

147. Id.

148. Rome Statute of the ICC, supra note 3, art. 5(1)(d). See supra text accompanying note 51 .

149. Rome Statute of the ICC, supra note 3, art. 5(2). 
exercise jurisdiction ...."150 Since the crime of aggression will fall under the ICC's jurisdiction through amendment procedures, State Parties, again, will have the opportunity to opt-out of this category of ICC jurisdiction. ${ }^{151}$ According to the United States, this is a significant problem, similar to the issue of adding new crimes. ${ }^{152}$ Another problem from the United States' position is that some states are advocating ICC jurisdictional conditions that are in "conflict with the Security Council and the UN charter[,]" although no specific conditions are mentioned in the Fact Sheet issued by the United States Department of State. ${ }^{153}$

\section{The Prosecutor}

The United States views the Office of the Prosecutor as potentially dangerous because the Prosecutor has the power to initiate an investigation "proprio motu" once two of the three judges on the Pre-Trial Chamber agree. ${ }^{154}$ The United States fears that, with a mere three people needed to pursue an investigation, politically motivated prosecutions could develop. ${ }^{155}$ The other two ways that the ICC may exercise jurisdiction is through a State Party referral or a Security Council referral. ${ }^{156}$ The United States feels that the State Party referral, and particularly the Security Council referral, leaves less room to question the motivation behind an investigation. ${ }^{157}$

The checks and balances of the Court are also in question by the United States because the Prosecutor is independent of the ICC, being "not responsible to an elected body or to the UN Security Council." "58 Since the Assembly will elect, and has the power to fire, the Prosecutor, "the character and motivations of the prosecutor will reflect the character and motivations of a majority of [S]tates [P]arties." ${ }^{59}$ The fear that the Prosecutor may feel compelled to act in favor of the interests of the majority of the States Parties is of great political concern. ${ }^{160}$

150. Id. art. 5(2). Since the Rome Statute will not be amended for seven years, it is presumed that the ICC will not have jurisdiction over the crime of aggression until sometime after July 2009. See id. art. 121, 123.

151. Id. art. 5, 121, 123. See U.S. Fact Sheet, supra note 138.

152. U.S. Fact Sheet, supra note 138.

153. Id.

154. Id. See Rome Statute of the ICC, supra note 3, art. 15(1), (3).

155. U.S. Fact Sheet, supra note 138.

156. Rome Statute of the ICC, supra note 3, art. 13.

157. See id. See also U.S. Fact Sheet, supra note 138.

158. U.S. Fact Sheet, supra note 138. See Rome Statute of the ICC, supra note 3, art. 42(1) (confirming that "the Prosecutor shall act independently as a separate organ of the Court").

159. Amann \& Sellers, supra note 19, at 389.

160. Id. 


\section{Reservations}

Reservations are used to limit the effects of treaties so that governments may ratify treaties "conditioned on certain additional terms" that are amenable to the country. ${ }^{161}$ "In a serious departure from common practice, the treaty does not permit states to take reservations." 162 This prohibition is especially problematic since the Rome Statute changed some definitions that have been long standing in other widely ratified treaties. ${ }^{163}$

\section{Complementarity ${ }^{164}$}

Article 17 of the Rome Statute requires that the ICC defer to the national when a State Party or a State has jurisdiction over the case and requests to handle an investigation or prosecution of an accused. ${ }^{165}$ The difficulty the United States has with this deferral is that, ultimately, it is up to the ICC to decide if the national is willing and able to handle the case. ${ }^{166}$ With that caveat, even though the Rome Statute purports in the preamble that it "shall be complementary to national criminal jurisdictions," 167 it is ultimately the ICC that dictates when it is appropriate to act on that notion. ${ }^{168}$ However, the statute states that national courts have priority jurisdiction over the ICC, even when the Security Council refers the case. ${ }^{169}$

\section{"Alternate Mechanisms"}

The United States has suggested more appropriate alternate mechanisms, to which the United States would be more amenable to agreement, but the ICC

161. See BlaCK's LAW DictionaRY 1049 (7th ed. 1999).

162. U.S. Fact Sheet, supra note 138. "No reservations may be made to this Statute." Rome Statute of the ICC, supra note 3, art. 120.

163. Panel Discussion, supra note 16, at 233. For example, the Statute makes bringing civilians of the occupier into occupied territories a war crime. See Rome Statute of the ICC, supra note 3, art. 8(2)(b)(viii). See supra note 48-51, for specific examples of changes.

164. The word "complementarity" comes from the adjective "complementary" and is common in physics. KRISTINA MISKOWIAK, THE INTERNATIONAL CRIMINAL COURT: CONSENT, COMPLEMENTARITY AND COOPERATION 45 (2000). "In the Preparatory Committee [of the International Criminal Court], the word was defined superficially as an expression 'to reflect the jurisdictional relationship between the international criminal court and national authorities, including national courts[.]" Id. (quoting UN Doc. A/51/22 Report of the Preparatory Committee on the Establishment of an International Criminal Court, Vol. I (proceedings of the Preparatory Committee during Mar.-Apr. and Aug. 1996, p. 30, para. 109).

165. Rome Statute of the ICC, supra note 3, art. 17(1). See U.S. Fact Sheet, supra note 138. 19.

166. Rome Statute of the ICC, supra note 3, art. 17(1). See U.S. Fact Sheet, supra note

167. Rome Statute of the ICC, supra note 3, at 1002.

168. See id. art. 17(2).

169. See Arsanjani, supra note 15 , at 28. 
has rejected the suggestions. ${ }^{170}$ The United States recognizes the need for punishment and accountability for these atrocities. ${ }^{171}$ Further, the United States fiercely advocates that domestic accountability should always be the most fundamental step in bringing these criminals to justice. ${ }^{172}$ Where the State is unable, the international community needs to intervene to assist with possible "political, financial, legal, and logistical support." 173 Where the State is not willing to investigate or prosecute the accused, there is already a mechanism in place for dealing with the State and the crimes committed - the UN Security Council. ${ }^{174}$ The United States points to the ad hoc tribunals established to prosecute criminals in the former Yugoslavia and Rwanda as successful examples. ${ }^{175}$

\section{OTHER ISSUES OF IMPORTANCE}

\section{A. The United States Attempts Bilateral Agreements}

The United States has offered resolutions to existing differences it has with the ICC through appropriate measures, such as suggesting amendments to agreements, along with some measures that critics view as inappropriate, such as threatening to pull all peacekeepers out of peacekeeping missions. ${ }^{176}$ Because these measures have not alleviated the fears of the United States, the United States has asked nations that are part of the ICC to sign bilateral agreements "exempting US officials from the possibility of surrender to the ICC."177

170. See U.S. Fact Sheet, supra note 138.

171. See id.

172. Id.

173. U.S. Fact Sheet, supra note 138.

174. Id.

175. Id.

176. See Chronology of US Anti-ICC Resolutions in the Security Council, THE INTERNATIONAL CRIMINAL COURT UPDATE (NEW YORK), Sept. 2002, at 1, available at http://www.iccnow.org/publications/update/iccupdateASPedition200208.pdf (last visited Oct. 27, 2003). Currently, through Resolution 1422, the United States' peacekeepers have immunity for a year. Id. A political cartoon in this article shows the International Criminal court sitting at a normal sized podium saying "You are charged with evading world justice - how do you plead?" and the United States sitting at a much bigger podium with the response of "Bigger." Id. at 7. On August 2, 2002, the American Servicemembers' Protection Act became law in the United States. American Servicemembers' Protection Act of 2002, Pub. L. No. 107-206, 116 Stat. 2002 (codified at 22 U.S.C. $\$ 7421$ (2002)). This Act confirms that the United States "will not recognize the jurisdiction of the International Criminal Court over United States nationals." Id. $\S 2002$ (11) (codified at 22 U.S.C. $\$ 7421(11)$ ) .

177. See US Launches Global Campaign for Immunity from ICC, THE INTERNATIONAL CRIMINAL COURT UPDATE (NEW YORK), Sept. 2002, at 2, available at http://www.iccnow.org/ publications/update/iccupdateASPedition200208.pdf(last visited Oct. 27, 2003). Absent these agreements, Americans will be subject to jurisdiction of the ICC in states that have ratified the Rome Statute because "[t]erritorial jurisdiction ... prevails over jurisdiction based on nationality[,]" unless it is an official military operation or an act performed against any other 
Currently, fourteen countries have agreed to support the agreement. ${ }^{178}$ Canada, the Netherlands, Norway, Slovenia, Switzerland, and Yugoslavia have publicly expressed reservations about the bilateral agreements. ${ }^{179}$

\section{B. Coalition for the International Criminal Court}

The Coalition for the International Criminal Court (CICC) includes over one thousand non-governmental agencies that are advocating on behalf of the ICC. ${ }^{180}$ According to the CICC, the fact that many of the United States' Allies, along with other democratic nations, will sit on the Assembly is sufficient to dispel any worries that the Prosecutor will have too much power because the Assembly will take action if politically motivated cases should arise. ${ }^{181}$ Although, it should be noted that under the duties of the Assembly enumerated in the Rome Statute, there is no mention of specific action for politically motivated prosecutions, nor is there any indication that the

armed forces where, under a NATO agreement, the "first right to try" is the homeland of the military personnel charged. AMERICAN BAR ASSOCIATION RECOMMENDATION, supra note 136, at 5-6.

178. Fact Sheet, The American Non-Governmental Organizations Coalition for the International Criminal Court, Chronology of the U.S. Opposition to the International Criminal Court (Nov. 18, 2002) at http://www.amicc.org/docs/UStimeline.pdf(last visited Oct. 27, 2003). The fourteen countries who have agreed, many of whom still need parliamentary approval, are: Afghanistan, the Dominican Republic, East Timor, El Salvador, Gambia, Honduras, Israel, the Marshall Islands, Mauritania, Micronesia, Palau, Romania, Tajikistan, and Uzbekistan. Id. Amnesty International is formally petitioning for governments not to sign the bilateral agreements stating that the agreements are "unlawful under international law." Amnesty International, International Justice, US Threats to the International Criminal Court, at http://web.amnesty.org/pages/int_jus_icc_us_threats (last visited Oct. 27, 2003). The CICC insists that the agreements will not protect Americans from ICC jurisdiction. See US Launches Global Campaign for Immunity from ICC, supra note 177. See Human Rights Watch, United States Efforts to Undermine the International Criminal Court: Article 98 Agreements, at http://www.iccnow.org/pressroom/factsheets/FS-HRW-Art98.doc (last visited Oct. 27, 2003), for a legal analysis of how the bilateral agreements may violate the Rome Statute.

179. US Launches Global Campaign for Impunity, supra note 177.

180. CICC Home Page, supra note 22, at http://www.iccnow.org/index.html (last visited Oct. 27, 2003). The CICC is a nominee for the 2002 Nobel Peace Prize. Coalition Nominated for Nobel Peace Prize, THe InTERnational CRIMINal COURT MONITOR (NEW YORK), Sept. 2002, at 13, available at http://www.iccnow.org/publications/monitor/22/Monitor22.200209 .english.pdf (last visited Oct. 27, 2003). See The Cato Institute, Policy Analysis, Reasonable Doubt: The Case Against the Proposed International Criminal Court (July 16, 1998), at http://www.cato.org/pubs/pas/pa-311.html (last visited Oct. 27, 2003) [hereinafter Cato Institute], for an opposing view of the International Criminal Court. Although one of the Cato Institute's missions is to limit government, the Policy Analysis regarding the International Criminal Court makes many strong arguments against the ICC. See id.

181. Justice Richard J. Goldstone, US Withdrawal from ICC Undermines Decades of American Leadership in International Justice, The International Criminal Court Monitor: The Newspaper of the NGO Coalition for the International Criminal Court (New York), Issue 21, June 2002, at 3 . 
Assembly will have any true power over the cases that the ICC tries. ${ }^{182}$ Interestingly, the CICC goes on to state that the "[p]reservation of the independence of the Prosecutor is critical for maintaining a fair and impartial Court." 183 The CICC also notes that the Security Council can stop any prosecution or investigation of any case and may renew that order indefinitely. ${ }^{184}$

The CICC claims, citing the complementarity policy that the ICC has adopted, that the Statute has "strong mechanisms" in place to ensure that the ICC is used as a last resort. ${ }^{185}$ However, the strength of those mechanisms is questionable when the ICC is the body that ultimately decides if a nation is willing and able to prosecute the accused. ${ }^{186}$ If the ICC decides that the nation is unwilling or unable to prosecute, it will prosecute against the nation's objection. ${ }^{187}$ Furthermore, the CICC criticizes the United States' position regarding the Security Council because the Security Council is a political body, and "the hallmark of a fair and effective justice system is its independence from political influence." 188 Finally, while the United States complains that the ICC undermines the sovereignty of non-State parties by claiming jurisdiction over nationals on State Party territory, the CICC reasons that the United States is the nation undermining other nations' sovereign rights by advocating that the ICC should not have jurisdiction over States that have not ratified the Rome Statute. ${ }^{189}$ The theory is that since all nations, including the United States, have the right to prosecute criminals on their soil, any State Party has the sovereign right to choose to prosecute criminals through the ICC. ${ }^{190}$ The CICC is disappointed with the position of the United States and urges the United States to participate in the ICC. ${ }^{191}$

182. See Rome Statute of the ICC, supra note 3, art. 112. The only enumerated duties that involve the Assembly of State Parties monitoring the ICC are found in article 112(2)(b), where the charge is to "[p]rovide management oversight to the Presidency, the Prosecutor and the Registrar regarding the administration of the Court;" and article 112(4) where the Assembly "may establish such subsidiary bodies as may be necessary, including an independent oversight mechanism for inspection, evaluation and investigation of the Court, in order to enhance its efficiency and economy." Id. art. 112(2)(b), (4). Because those duties are managerial duties, the Statute does not suggest that the Assembly will have any power over the ICC to halt any politically motivated case. See id.

183. Goldstone, supra note 181 , at 3.

184. Id. This power of the Security Council is found in article 16 of the Rome Statute. Rome Statute of the ICC, supra note 3, art. 16. See supra Part One II.B (discussing the Security Council's role in deferring trial and the votes required to do so).

185 . Goldstone, supra note 181 , at 3 .

186. See Rome Statute of the ICC, supra note 3, art. 17.

187. See id.

188. Goldstone, supra note 181 , at 3 .

189. See id.

190. See id.

191. See id. at 11. 


\section{The American Bar Association}

The American Bar Association (ABA) has formerly recommended that the United States accede to the Rome Statute. ${ }^{192}$ One of the motivations behind the United States' signature of the Rome Statute, according to the ABA, would have been eligibility in the Assembly, which would lead to the United States having influence over the future of the ICC including "the adoption of the Rules of Procedure and Evidence, the Elements of Crimes, and the definition of aggression." 193

The ABA rejects the United States' argument concerning the ICC's jurisdiction over non-State parties because even if there were no Statute, if an American committed offenses on another nation's territory, that nation would have every right to prosecute that American, with or without the ICC. ${ }^{194}$ The ABA further argues that the protections the Rome Statute offers defendants is consistent with the Bill of Rights despite the lack of a right to a jury trial. ${ }^{195}$ The Constitution excludes military service personnel from the right of a grand jury during time of war or public danger, and the trial by jury provision is for a jury in the district where the crime was committed. ${ }^{196}$

Further, the ABA proposes that the Office of the Prosecutor of the ICC has "less authority than the typical County Prosecutor or District Attorney in the United States[,]" limiting yet another argument the United States has proposed. ${ }^{197}$ In the ICC, the Prosecutor must obtain agreement from the PreTrial Chamber before fully pursuing an investigation that the Prosecutor has initiated. ${ }^{198}$

The ABA concludes by acknowledging that the Rome Statute "bears the imprint of the best of American legal professionalism, expertise and values[,]" because many "American diplomats, government officials, scholars, and representatives of nongovernmental organizations" were included in its

192. ABA RECOMMENDATION, supra note 136, at 1 . It should be noted, however, that on August 11-12, 1992, the American Bar Association Task Force on an International Criminal Court recommended to the United States government that there were "numerous important legal and practical issues identified" that the United States should work towards resolving. REPORT of THE TASK Force on an INTERnational CRIMINAL COURT OF THE AMERICAN Bar AsSOCIATION 1 (Alaire Bretz Rieffel ed., 1994). The recommendation listed four principles: 1) Member states should be able to declare the crimes that they recognize the ICC as having jurisdiction over; 2) Both the national State and the territory State should be a party to the Statute before a person is tried before the court; 3 ) The fundamental rights of the accused should be protected; 4) Sanctions should enforce the obligation of State Parties. See id. The Statute does not convey the first or second principles that the ABA found important. See Rome Statute of the ICC, supra note 3, art. 112.

193. ABA RECOMMENDATION, supra note 136 , at 1 .

194. See id. at 7.

195. Id.

196. See id. at 1, 7; U.S. CONST. amend. V, VI.

197. See ABA RECOMMENDATION, supra note 136 , at 8.

198. See id. at 8; Rome Statute of the ICC, supra note 3, art. 15(3). 
negotiations. ${ }^{199}$ While admitting that some provisions of the Statute have room for criticism, the ABA nevertheless urges the United States to join the ICC, arguing that "[t]he security interests of the United States and of its service members and officials are as fully protected as reasonably could be provided for by an international treaty."200

\section{CONCLUSION OF PART ONE}

While the International Criminal Court, in its permanency, is seen by many nations-ninety-two as of this writing-as positive progress for the prosecution of heinous crimes, the United States refuses to adhere. ${ }^{201}$ Some of the arguments made by the United States are viable concerns, while others are not as compelling because there Rome Statute provides safeguards. ${ }^{202}$ There are strong arguments for why the United States should join the ICC as well as equally strong arguments for why it should not. ${ }^{203}$

\section{PART TWO: IS THE INTERNATIONAL CRIMINAL COURT ANY BETTER THAN THE NUREMBERG TRIALS?}

\section{THE NUREMBERG TRIALS}

\section{A. Introduction}

After World War II, the United States, the United Kingdom, the Union of Soviet Socialist Republics (USSR) (Russia), and France, under a Charter drafted in London along with other Allies, ${ }^{204}$ formed an International Military Tribunal (IMT) to prosecute German war criminals. ${ }^{205}$ Twenty-four defendants were initially charged, one being in absentia. ${ }^{206}$ The defendants,

199. ABA RECOMMENDATION, supra note 136 , at 9.

200. Id. at 9 .

201. See Coalition for the InT'L Criminal Court, State Parties to the Rome STATUTE OF THE ICC (2002), at http://www.iccnow.org/countryinfo/Ratificationsby UNRegions.pdf (last visited Oct. 27, 2003).

202. See discussion supra Part One II-III.

203. See id.

204. The Allies were a group of nations that agreed to cooperate with each other during the war. See THE OXFORD POCKET DICTIONARY AND THESAURUS (Frank R. Abate ed., 1997).

205. THE LAW OF WAR CRIMES NATIONAL AND INTERNATIONAL APPROACHES 171 (Timothy L.H. McCormack \& Gerry J. Simpson eds., 1997) [hereinafter LAW OFWAR CRIMES]. The other Allies who signed the Charter, but did not take part in the prosecutions, were: "Australia, Belgium, Czechoslovakia, Denmark, Ethiopia, Greece, Haiti, Honduras, India, Luxemburg, the Netherlands, New Zealand, Norway, Panama, Paraguay, Poland, Uruguay, Venezuela and Yugoslavia." Id. at 172 n.3. Interestingly, this trial was intended to be the "first of a series of trials, but a combination of inertia, the Cold War, and a desire to get on with the peace ... resulted in no more trials ...." Id. at 172.

206. Id. at 172. 
among others, were top political figures, "[f]oreign [m]inisters, leading generals and navy commanders, [and] prominent Nazi party administrators ...."207 Of the twenty-four, one committed suicide, one was deemed unfit for trial, "three were acquitted, twelve (including the absent [defendant]) were sentenced to death, three received life sentences and four received prison terms." 208 There are two theories regarding how the Allies had the power to prosecute the war criminals of defeated Germany: 1) At the end of the war, the Allies became the official German government as the government of Germany ceased to exist; ${ }^{209}$ or 2) The Allies were "exercising the authority of the international community operating on a type of universal jurisdiction theory." 210 The London Charter (Charter) gave the IMT jurisdiction over "crimes against peace, ${ }^{211}$ war crimes, ${ }^{212}$ and crimes against humanity." ${ }^{213}$ To prosecute crimes committed prior to the war, the IMT also charged defendants with conspiracy to wage aggressive war, which was the "common plan or conspiracy" charge. ${ }^{214}$ The Charter also effectively prevented the defendants from using the "following orders" defense. ${ }^{215}$

207. Id.

208. Id. See infra note 234, for a list of defendants, along with the positions they held.

209. Donald A. Wells, War CRIMes AND Laws OF WAR 97 (2d ed. 1991). See LaW OF WAR CRIMES, supra note 205, at 172.

210. Id.

211. Id. Crimes against peace was defined as "planning, preparation, initiation or waging a war of aggression, or a war in violation of international treaties, agreements or assurances, or participation in a common plan or conspiracy for the accomplishment of any of the foregoing[.]" Id. at 173.

212. Id. at 172. War crimes was defined as:

[V]iolations of the laws or customs of war. Such violations shall include, but not be limited to, murder, ill-treatment or deportation to slave labor or for any other purpose of civilian population of or in occupied territory, murder or ill-treatment of prisoners of war or persons on the seas, killing of hostages, plunder of public or private property, wanton destruction of cities, towns or villages, or devastation not justified by military necessity[.]

Id. at 173.

213. LAW OF WAR CRIMES, supra note 205 , at 172 . Crimes against humanity was defined as:

[M]urder, extermination, enslavement, deportation, and other inhumane acts committed against any civilian population, before or during the war, or persecutions on political, racial or religious grounds in execution of or in connection with any crime within the jurisdiction of the Tribunal, whether or not in violation of the domestic law of the country where perpetrated. Id. at 173.

214. Court TV, The Indictments, at http://www.courttv.com/casefiles/nuremberg/ indictments.html (last visited Oct. 27, 2003) [hereinafter The Indictments].

215. LAW OF WAR CRIMES, supra note 205, at 174. 


\section{The Charges}

\section{a. Count One: Conspiracy to Wage Aggressive War}

The United States was assigned to prosecute the conspiracy count because it was the most difficult and controversial. ${ }^{216}$ The defendants charged with this count "were accused of agreeing to commit crimes."217 At the time, continental law did not recognize conspiracy as a crime; it "remained controversial throughout the trial." 218 It has been argued that this count was based on Nazi policymaking and gave the defendants a chance to exculpate themselves using the confused state of the command structure and ignorance. ${ }^{219}$

\section{b. Count Two: Crimes Against Peace}

The British prosecutors tackled crimes against peace. ${ }^{220}$ This count was based on the Germans violation of international agreements that were already in place such as the Kellogg-Briand Pact (Pact). ${ }^{221}$ The signatories to the Pact agreed to "renounce[] war as an instrument of national policy . . .."222 Germany was not only a party to the Pact, but was, ironically, the first country to sign. ${ }^{23}$ The problem with the violation of this international agreement is that the Pact did not define "aggressive war" and, more importantly, it did not provide any penalties for violations. ${ }^{224}$

\section{c. Count Three: War Crimes}

The USSR and France combined to prosecute the charges of war crimes. ${ }^{25}$ The USSR handled the crimes committed in the East, while France

216. The Indictments, supra note 214.

217. Id.

218. Id.

219. Id.

220. Id.

221. Id. The Kellogg-Briand Pact was signed on August 27, 1928 and entered into force on July 24, 1929. GLUECK, supra note 5, at 17. See Kellogg-Briand Pact, opened for signature Aug. 27, 1928, 27 I.L.M. 1699 (1998) (entered into force July 24, 1929). See e.g., GLuECK, supra note 5, at 17-22. The Kellogg-Briand Pact made war a crime but gave no provisions for punishing violations. Id.

222. The Indictments, supra note 214.

223. GLUECK, supra note 5, at 17.

224. The Indictments, supra note 214. The Pact "failed to make violations of its terms international crimes punishable either by an international tribunal or by national courts." GLUECK, supra note 5, at 17. The Soviet Union violated the Pact when they invaded Finland, Poland and the Baltics and again when they "schemed with Hitler to sign the Nazi-Soviet NonAggression Pact in 1939[,]" secretly dividing Poland. The Indictments, supra note 214.

225. The Indictments, supra note 214. 
handled the crimes committed in the West. ${ }^{226}$ Count three dealt with "acts that violated traditional concepts" of war such as "the use of slave labor; bombing civilian populations; the Reprisal Order ${ }^{227}$... ; [and] the Commando Order ${ }^{228}$ . . .." This count was the least controversial as it was more settled in precedents such as The Hague Conventions ${ }^{229}$ and The Geneva Conventions. ${ }^{230}$

\section{d. Count Four: Crimes Against Humanity}

For the final count, Russia and France joined forces again, dividing the responsibility along the East and the West respectively. ${ }^{231}$ The count of crimes against humanity was "applied to defendants responsible for the death camps, concentration camps and killing rampages in the East." 232 Historically, these were crimes "committed by a government against its own people" so the addition of the crime in the London Charter was questioned. ${ }^{233}$

\section{The Prosecution}

The prosecuting nations selected defendants in an arbitrary fashion mostly based on their notoriety and their delegated authority. ${ }^{234}$ The

226. Id.

227. Id. The Reprisal Order "required that 50 Soviet soldiers be shot for every German killed by partisans." Id. A defendant being prosecuted by the IMT signed this order. Id.

228. Another defendant at the Nuremberg Trials signed the Commando Order, which ordered "downed Allied airmen shot rather than taken captive." The Indictments, supra note 214.

229. Id. In 1899 and 1907, The Hague Conventions prescribed rules on the treatment of prisoners of war and civilians as well as outlawed some weapons such as dum-dum bullets and poison gas. Id.

230. Id. In 1864 and 1906, The Geneva Conventions prescribed treatment of the sick and wounded. Id.

231. The Indictments, supra note 214.

232. Id.

233. Id.

234. Id. Although, Hans Fritzsche was a "minor official" in a propaganda ministry but the Russian authority that held him insisted that he was charged. Id. Fritzsche was acquitted of all charges by the IMT, but Russia dissented in that part of the judgment. Judgment of the International Military Tribunal (Sept. 30 and Oct. 1, 1946), in THE TRIAL OF GERMAN MAJOR WaR Criminals by THE INTERnational MiltTaRy Tribunal SITting at NuREMBERG GERMANY 128, 138 (1946) [hereinafter Judgment of IMT]. The defendants, in alphabetical order, were:

KARL DOENITZ[,] Supreme Commander of the Navy; in Hitler's last will and testament he was made Third Reich President and Supreme Commander of the Armed Forces[,] Sentenced to 10 Years in Prison[;] HaNS FRANK[,] GovernorGeneral of occupied Poland[,] Sentenced to Hang[;] WILHELM FRICK[,] Minister of the Interior[,] Sentenced to Hang[;] HANS FRITZSCHE[,] Ministerial Director and head of the radio division in the Propaganda Ministry[,] Acquitted[;] WalTHER Funk[,] President of the Reichsbank[,] Sentenced to Life in Prison[;] HERMANN GoERING[,] Reichsmarschall, Chief of the Air Force[,] Sentenced to 
prosecution began with Justice Robert H. Jackson, Chief Prosecutor for the United States of America. ${ }^{235}$ In his opening remarks, Justice Jackson acknowledged that this case would not be tried as a typical case by American standards or by the standards of any other established justice system. ${ }^{236} \mathrm{He}$ was particularly concerned about how quickly the Nuremberg trials were proceeding; ${ }^{237}$ he noted that American crimes of much smaller consequence would take at least a year. ${ }^{238}$ Yet, in Nuremberg, it took less than eight months despite the myriad of evidence to evaluate, witnesses to interview, and documents to examine. ${ }^{239}$ The evidence against the Germans was strong

Hang[;] RUDOLF Hess[,] Deputy to Hitler[,] Sentenced to Life in Prison[;] ALFRED JODL[,] Chief of Army Operations[,] Sentenced to Hang[;] ERNST KALTENBRUNNER[,] Chief of Reich Main Security Office whose departments included the Gestapo and SS[,] Sentenced to Hang[;] WILHELM KEITEL[,] Chief of Staff of the High Command of the Armed Forces[,] Sentenced to Hang[;] ERICH RAEDER[,] Grand Admiral of the Navy[,] Sentenced to Life in Prison[;] ALFRED ROSENBERG[,] Minister of the Occupied Eastem Territories[,] Sentenced to Hang[;] FRITZ SAUCKEL[,] Labor leader[,] Sentenced to Hang[;] HJALMAR SCHACHT[,] Minister of the Economics[,] Acquitted[;] ARTHUR SEYSSINQUART[,] Commisar of the Netherlands[,] Sentenced to Hang[;] ALBERT SPEER[,] Minister of Armaments and War Production[,] Sentenced to 20 Years in Prison [;] Juluus STREICHER[,] Editor of the newspaper Der Sturmer, Director of the Central Committee for the Defence against Jewish Atrocity and Boycott Propaganda[,] Sentenced to Hang [;] CONSTANTIN VON NEURATH[,] Protector of Bohemia and Moravia[,] Sentenced to 15 Years in Prison [;] FRANZ VON PAPEN[,] One-time Chancellor of Germany[,] Acquitted[;] JOACHIM VON RIBBENTROP[,] Minister of Foreign Affairs[,] Sentenced to Hang[;] BALDUR VON SCHIRACH[,] Reich Youth leader[,] Sentenced to 20 Years in Prison.

Court TV, The Defendants, at http://www.courttv.com/casefiles/nuremberg/defendants.html (last visited Oct. 27, 2003). See Judgment of IMT, supra, at 84-128, 130-31. Martin Bormann, second in command, was tried in absentia and sentenced to hang. Judgment of IMT, supra, at 131. In an interview with Court TV, Drexel Sprecher, Assistant United States Prosecutor, said that the Tribunal made a mistake by including Schacht as a defendant. Court TV, Interview with Nuremberg Trial Prosecutor Drexel Sprecher, at http:/www.courttv.com/casefiles/ nuremberg/sprecher.html (last visited Oct. 27, 2003) [hereinafter Sprecher Interview]. See Court TV, Who's Who, at http://www.courttv.com/casefiles/nuremberg/participants.html (last visited Oct. 27, 2003) (confirming Sprecher as an Assistant U.S. Prosecutor) [hereinafter Who's Who]. While Schacht may have originally had some connections prior to the war, he eventually was sent to concentration camps by Hitler, not as part of Hitler's regime, but as a prisoner for "having conspired against Hitler." Sprecher Interview, supra, at http://www.courttv.com/ casefiles/nuremberg/sprecher.html. Schacht was in a concentration camp "nearly a year before the trial began." Id.

235. Opening Speech of the Chief Prosecutor for the United States of America (Nov. 21, 1945), in THE TRIAL OF GERMAN MAJOR WAR CRIMINALS BY THE INTERNATIONAL MILITARY TRIBUNAL SITTING AT NUREMBERG GERMANY 3 (1945) [hereinafter Opening Speech of Justice Jackson].

236. Id. at 4. "I should be the last to deny that the case may well suffer from incomplete researches, and quite likely will not be the example of professional work which any of the prosecuting nations would normally wish to sponsor." Id.

237. See id.

238. See id.

239. See id. 
because the Germans were such meticulous record keepers, not to mention that they were photographed while performing some of the very deeds for which they were now being prosecuted. ${ }^{240}$ Moreover, a concentration camp film was used "as a dramatic way of showing some of the evils that had happened."241

The prosecution had only thirty-three witnesses that gave oral testimony at the IMT. ${ }^{242}$ As a result, the case was decided on the immense amount of evidence that the prosecution presented, which consisted of "documentary evidence, captured by the Allied armies in German army headquarters, Government buildings, and elsewhere."243

\section{The Defense}

The London Charter gave the defendants the "right to an attorney of their choice," which would be paid for by the Allies. ${ }^{244}$ The defendants were also able to present evidence and cross-examine witnesses. ${ }^{245}$ When asked whether the defendants at Nuremberg received an adequate defense, Drexel Sprecher, United State Assistant Prosecutor, said that there was some "very good [defense] counsel." $246 \mathrm{Mr}$. Sprecher particularly was impressed with Otto Kranzbuehler, defense counsel for Karl Doenitz, saying that he was "one of the brightest counsel . . . anywhere."247 Another impressive attorney was Dr. Rudolf Dix, defense counsel for Hjalmar Schacht, who, prior to the Nazi's taking power, was the President of the German Bar Association. ${ }^{248}$ Some of the defendants themselves were lawyers who also helped in the defense. ${ }^{249}$

However, some would argue that the defense offered was not only unfair, but also conflicted with the interests of the IMT. For example, the defense's witnesses were summoned by the IMT; therefore, the prosecution was aware of who the defense would call as witnesses and had adequate time

240. Opening Speech of Justice Jackson, supra note 235, at 6.

241. Sprecher Interview, supra note 234.

242. Judgment of IMT, supra note 234, at 2.

243. Id. at 3.

244. Court TV, The Creation of the Tribunal and the Law Behind It, at http://www.courttv.com/casefiles/nuremberg/law.html (last visited Oct. 27, 2002) [hereinafter Creation of the Tribunal].

245. Id.

246. Sprecher Interview, supra note 234. See Who's Who, supra note 234 (confirming that Drexel Sprecher was an Assistant United States Prosecutor).

247. Sprecher Interview, supra note 234. See Who's Who, supra note 234 (confirming that Otto Kranzbuehler was a German Navy judge and defense counsel for Doenitz).

248. Sprecher Interview, supra note 234. See Who's Who, supra note 234 (confirming that Dr. Rudolf Dix was counsel for Schacht).

249. Sprecher Interview, supra note 234. 
to prepare to impeach those witnesses or attack their character. ${ }^{250}$ Conversely, the defense did not have the advantage of knowing who the prosecution would call as witnesses. ${ }^{251}$ In one instance, the defense even made a motion asking that the prosecution forewarn them of witnesses, which was rejected by the IMT. ${ }^{252}$ Another inequality existed in pre-examination discussions with witnesses. ${ }^{253}$ The prosecution could freely examine any of the defense's witnesses prior to trial, but the defense was not permitted to speak with any of the prosecution's witnesses prior to trial. ${ }^{254}$ Even more remarkable is that the defense made a motion asking to examine the documents in the possession of the prosecution; this motion was also denied. ${ }^{255}$

\section{E. Legal Issues at Nuremberg}

The London Charter set out the rules that the Nuremberg Court would use in prosecuting the defendants. ${ }^{256}$ The rules were a combination of American law and Continental law. ${ }^{257}$ Some aspects of the Charter literally mixed the two forms of law, for instance, the evidence presented. ${ }^{258}$ The United States required only enough evidence to establish probable cause to place a defendant on trial, while continental law required that all of the evidence be presented before a defendant is put on trial. ${ }^{259}$ The IMT combined the laws so that some of the evidence was required, but not all. ${ }^{260}$

Another aspect of the trial that differed from American law is that the defendants were given the opportunity to present unsworn statements at the conclusion of the trial. ${ }^{261}$ Furthermore, in American courts, the accused has a constitutionally protected right under the Sixth Amendment "to be confronted with the witnesses against him[.]" ${ }^{262}$ At Nuremberg, hearsay

250. See August Von Knieriem, The Nuremberg Trials 158 (Dr. iur. Elizabeth D. Schmitt trans., Henry Regnery Company 1959). Dr. August von Knieriem (author) was prosecuted in one of the trials conducted by a United States military tribunal post IMT. Max Rheinstein, Preface to the American Edition, THE NuREMBERG TRIALS ix (Dr. iur. Elizabeth D. Schmitt trans., Henry Regnery Company 1959). He was found innocent of all charges. Id.

251. Id.

252. See id.

253. Id.

254. Id.

255. VON KNIERIEM, supra note 250, at 158.

256. Creation of the Tribunal, supra note 244.

257. Id. In Continental law, the judge asks many questions of the witnesses, as opposed to American law where counsel asks the questions. Sprecher Interview, supra note 234. This notion may be carried forward at the ICC because one of the rights of the accused is "[t]o examine, or have examined, the witnesses against him or her[,]" suggesting that judges could question witnesses. Rome Statute of the ICC, supra note 3, art. 67(e).

258. Creation of the Tribunal, supra note 244.

259. Id.

260. Id.

261. Id.

262. U.S. CONST. amend. VI. 
evidence was admitted as long as it had probative value; therefore, statements were used in lieu of having witnesses on the stand for the defense to crossexamine. ${ }^{263}$

Another American constitutional guarantee that was unavailable at Nuremberg is the right to a jury trial. ${ }^{264}$ Moreover, there was no right to appeal the verdict of the IMT. ${ }^{265}$ One of the most controversial differences between the rules of the Nuremberg court and American law is that the laws were imposed ex post facto. ${ }^{266}$ The laws that the defendants were accused of violating were, at that time, international laws that applied to nations, not individuals. ${ }^{267}$

\section{ANALYSIS OF THE INTERNATIONAL CRIMINAL COURT IN RELATION TO THE NUREMBERG TRIALS}

\section{A. Introduction}

Since the United States held such a key role in the Nuremberg trials, ${ }^{268}$ it would seem only natural for the United States to agree to be bound by the Rome Statute. But, as is apparent, the United States is not only against the ICC, but actively seeking to undermine it, at least with respect to American defendants. ${ }^{269}$

\section{B. Differences in the Two Courts}

The most obvious difference between the two courts is that Nuremberg was a tribunal, therefore temporary, and the ICC is permanent. ${ }^{270}$ Since Nuremberg was a temporary tribunal, the IMT could focus on the issue at hand. As a permanent court, the ICC will have other issues such as remaining an economically feasible unit so that the ICC can continue to operate. The Rome Statute does not expressly state what the ICC will do when there is no one to prosecute. The ICC may feel as though it needs a continuous caseload to ease this burden.

263. See Creation of the Tribunal, supra note 244.

264. See id. See also U.S. ConST. amend. VI.

265. Creation of the Tribunal, supra note 244. The Control Council of Germany, which was the Allied occupation government, could reduce or change the sentences that the defendants received at the IMT. Id. However, the request of the defendants who did seek clemency was rejected. Id.

266. See id.

267. Court TV, The Trial's Legacy, at http://www.courttv.com/casefiles/nuremberg/ legacy.html (last visited Oct. 27, 2003).

268. See LAW OF WAR CRIMES, supra note 205, at 171.

269. See supra Part One II-III.

270. See LAW OF WAR CRIMES, supra note 205, at 171; Rome Statute of the ICC, supra note 3 , art. 1 . 
The most notable difference between the two courts is that, at Nuremberg, the Allied forces were able to collect an immense amount of data because they were the victors of the war. Consequently, they were able to take the evidence without the hindrance of legal procedures. ${ }^{271}$ Since the Germans were such meticulous record keepers, the evidence that the Allies recovered was detailed and convincing enough to convict most of the defendants. ${ }^{272}$ This scenario set a perfect stage for international criminal prosecutions; however, the International Criminal Court is not likely to have it as easy. Presumably, the atrocities that the ICC will hear most likely will not come from a war in which the Allies can collect all of the evidence against the defendants with disregard for legal procedure. Even if there was a war, the Nuremberg trials are a lesson to war criminals not to record, in such excessive detail, the events that may later be considered as war crimes; therefore, the evidence linking specific individuals to crimes will most likely be sparse.

Besides the overwhelming difference of access to evidence, there are many other differences between the two courts. For instance, at Nuremberg, the defendants were already in custody. ${ }^{273}$ The ICC requests that State Parties arrest accused criminals when charges are brought and is silent on a situation where a State Party refuses. ${ }^{274}$ Moreover, one defendant at Nuremberg, Martin Borman, was tried in absentia and sentenced to death. ${ }^{275}$ Article 63 of the Rome Statute clearly states that the "accused shall be present during trial."276

The IMT's application of ex post facto laws is debatable, ${ }^{277}$ but the ICC will have no such issues as the ICC only has jurisdiction for crimes committed after July 1, 2002, when the Statute entered into force. ${ }^{278}$ The only debatable aspect of the ICC's jurisdiction in this respect is jurisdiction over nationals of non-party States. ${ }^{279}$

The defense at Nuremberg had problems knowing who the prosecution would call as witnesses as well as gaining access to evidence that the prosecution planned to use. ${ }^{280}$ The Rome Statute provides for Rules of Procedure and

271. See LAW OF WAR CRIMES, supra note 205, at 172; see also supra Part Two I-C.

272. See Opening Speech of Justice Jackson, supra note 235, at 6; LAW OF WAR CRIMES, supra note 205, at 172. See also supra Part Two I.C.

273. Cato Institute, supra note 180.

274. Rome Statute of the ICC, supra note 3, art. 59.

275. See JUDGMENT OF IMT, supra note 234, at 131.

276. Rome Statute of the ICC, supra note 3, art. 63(1). In exceptional circumstances, where the defendant continually disrupts the proceedings, the ICC may remove the defendant and provide the defendant with alternative mechanisms for viewing the trial and communicating with counsel. Id. art. 63(2).

277. See supra Part Two I.A.

278. See Rome Statute of the ICC, supra note 3, art. 11(1). As each State becomes a party to the Statute, the court will only have jurisdiction for crimes committed after the entry into force of the Statute for that State. Id. art. 11(2).

279. See supra Part One III.B.

280. See supra Part Two I.D. 
Evidence, which should alleviate that problem at the ICC. ${ }^{281}$ Finally, one of the more compelling differences with the ICC is that there is an appeals process, ${ }^{282}$ which was lacking at Nuremberg. ${ }^{283}$

\section{Familiar Issues with Both Courts}

One familiar issue in both Nuremberg and the ICC is that both have the same category of crime that is still as controversial now as it was then: Nuremberg with the conspiracy to wage aggressive war; the ICC with the crime of aggression. ${ }^{284}$ Additionally, both Nuremberg and the ICC crimes include war crimes and crimes against humanity, although definitions for the crimes were greatly expanded in the Rome Statute. ${ }^{285}$

The ICC and Nuremberg each provide the defense with counsel. Nuremberg paid for each defendant to have an attorney of the defendant's choosing. ${ }^{286}$ The Rome Statute provides that, if the accused does not have legal counsel, the ICC will assign counsel without charge to the accused if insufficient means is shown. ${ }^{287}$ Nuremberg may seem somewhat more just in this respect because the accused made the choice of who would represent them, whereas, at the ICC, legal assistance will be assigned to those who do not have it and only pay when the accused is unable. ${ }^{288}$ On the other hand, with the permanent ICC, attorneys around the world will become familiar with the process of defending the accused. Since Nuremberg combined American law and Continental law, the defense attorneys probably were not as effective as in their national courts. ${ }^{289}$ Eventually, attorneys with an expertise for defending ICC defendants will be available and capable of giving a defense in the sense that the American legal system is accustomed to.

Furthermore, hearsay evidence is allowed in both instances. This is probably because both courts exclude trial by jury. Therefore, with a bench trial, there is not as great of a potential for unfair prejudice to the defendant. Additionally, without hearsay evidence, a lot of evidence is likely to be left out, leaving a just decision out of reach.

281. See Rome Statute of the ICC, supra note 3, art. 69; Report of the Preparatory Commission for the International Criminal Court, U.N. Preparatory Commission for the International Criminal Court, Finalized Draft Text of the Rules of Procedure and Evidence (Nov. 2, 2000), U.N. Doc. PCNICC/2000/1/Add.1, for a finalized draft of the Rules of Procedure and Evidence.

282. See Rome Statute of the ICC, supra note 3, art. 81; supra Part One I.I.

283. Creation of the Tribunal, supra note 244.

284. See supra Part Two I.A.; Rome Statute of the ICC, supra note 3, art. 5.

285. See LAW OF WAR CRIMES, supra note 205, at 172; Rome Statute of the ICC, supra note 3, art. 5. Compare supra note 212, 213 with supra note 49, 50.

286. See supra Part Two I.D.

287. Rome Statute of the ICC, supra note 3, art. 55(2)(c).

288. See Creation of the Tribunal, supra note 244. See also Rome Statute of the ICC, supra note 3, art. 55(2)(c).

289. See supra Part Two I.E. 
Finally, the Nuremberg trials prosecuted top political figures for the atrocities that occurred. ${ }^{290}$ The Rome Statute devotes Article 27 solely to reinforce the notion that official capacity is irrelevant to the provisions of the Statute, including dismissing any immunities, national or international, that flow from an official capacity position. ${ }^{291}$

\section{CONCLUSION}

Is the International Criminal Court better than Nuremberg? In some ways, yes it is. There is a process in place with the ICC, crimes are predefined, there are Elements of Crime, Rules of Procedure and Evidence, and, most importantly, there is an appeals process. Yet, even with these improvements, and even though the United States instigated the Nuremberg Trials, the United States is unwilling to join the ICC. Why? One might think it is because of the issues that make the ICC worse than Nuremberg. One concern is that once the ICC is fully staffed, it will need the influx of continuous cases in order to ward off extinction. At some point, when all of the appropriate ICC cases have been prosecuted, then what will it do? Fearfully, the ICC will start pursuing cases that may be offensive but are not of the truly heinous nature aligned with the intent of the ICC. Because Nuremberg was a tribunal, there was a natural end to the proceedings.

Bothersome too is that at Nuremberg, the Allies, collectively as nations, decided to prosecute the defendants in an international tribunal. All of the nations were sufficiently convinced that the atrocities were heinous enough to warrant such an immense undertaking of bringing together an international tribunal. Cases of the ICC will require no such vigor because the ICC is already established and awaiting cases. Even more striking is that as few as three people, as opposed to many nations, could make the determination to investigate and prosecute a crime. When crimes are of such a heinous nature as to come before any international tribunal, is it appropriate that three individuals alone bring that decision to the world? Will the world accept the determination of these three individuals?

While these questions are outside of the scope of this paper, they are important. The United States must think about these questions in deciding what path to take regarding the International Criminal Court. The problem with the United States is that, as the super power, little is gained from acceding to the ICC because the United States is capable of taking care of itself in situations where the ICC would get involved. On the other hand, the risk involved if the United States does sign the Statute is having American peacekeepers tried for crimes in front of an international tribunal that the 
United States does not agree with. Is that really fair when Americans did not have to be on that peacekeeping mission in the first place?

Apparently, the United States does not think that the International Criminal Court is better than Nuremberg since it fully supported Nuremberg and does not support the ICC in its current form. The Nuremberg Trials served a noble purpose, limited in its scope. There were atrocities that needed to be punished, many powerful nations agreed, and the atrocities were punished. The International Criminal Court, structured as it is, does not give quite the same amount of deliberation as the Nuremberg trials. So, in the end, Justice Jackson's promise is not empty - the United States is not "laying down a rule of criminal conduct against others" that it is unwilling to have invoked against Americans. ${ }^{292}$ The United States does not think that the open-ended rule of criminal conduct that the International Criminal Court will prosecute should be invoked against anyone. 